\title{
Human capital of the Karelian Arctic in the implementation of the special economic regime of the region
}

\author{
Aleksander Volkov ${ }^{1, *}$ \\ ${ }^{1}$ The institute of Economics of the Karelian Scientific Centre of the Russian Academy of Sciences, \\ RAS, 50 A. Nevsky Ave., 185030, Petrozavodsk, Republic of Karelia, Russia
}

\begin{abstract}
This article presents the results of a field study of the state and development of the human capital in the Karelian Arctic as a factor in sustainable development of the region during the transition to a new economic and legal regime. The focus of the scientific research is the assessment by the citizens of the level of their well-being and the ability to meet various family needs, personal income planning possibilities, correspondence of the current place of work to the training received in an educational institution. Brief conclusions are made on the indicated aspects of the development of the human capital in the Karelian Arctic region. Data were obtained and an analysis of the situation was made both for the Karelian Arctic as a whole, and for individual municipal districts included in this region. Further research activities to deepen scientific knowledge about the state and trends in the development of the human capital in Arctic Karelia and the Arctic zone of Russia as a whole have been identified. The issues under study are one of the key ones in determining the parameters of the created special economic and legal regime, which applies to Arctic Karelia.
\end{abstract}

\section{Introduction}

The development and adoption of strategic documents for the development of the Arctic zone of the Russian Federation (hereinafter the AZRF), the updating of the management tools for regional development in the context of the implementation of a new special economic and legal regime and the entry of new territories into the AZRF require updating and improving knowledge about the socio-economic processes in the Russian Arctic. Thus, in particular, in the Strategy for the Development of the AZRF until 2035, the implementation of the main tasks in the field of economic development of the Arctic zone is assumed through the implementation of measures that include:

- introduction of a special economic regime in the Arctic zone, contributing to the transition to a circular economy, private investment in geological exploration, creation of new and modernization of existing industrial productions, development of science-intensive and high-tech industries, etc.

\footnotetext{
${ }^{*}$ Corresponding author: kov8vol@gmail.com
} 
- adjusting the system of basic professional educational programs and admission targets for training at the expense of budgetary allocations from the federal budget, budgets of the constituent entities of the Russian Federation, local budgets to educational organizations located in the Arctic zone, in accordance with the demand forecast for qualified and highly qualified personnel;

- $\quad$ systematic provision of state support measures to the economically active population of Russia ready to relocate (resettle) to the Arctic zone in order to carry out labor activities [1].

The full implementation of these measures is possible only on the basis of the development of new management mechanisms that are most effective in using the existing resources for the development of the Arctic regions, taking into account the existing economic, legal, political, socio-demographic, technological and other constraints [2]. Nevertheless, the human capital of the territories is one of the most important development resources. The relevance of the study of the Karelian Arctic is dictated primarily by the fact that this region has become part of the AZRF relatively recently [3,4], as well as by the novelty of the format of the proposed development in the context of global projects for the development of the Russian Arctic. In addition, the northern territories of the Republic of Karelia are studied relatively poorly from the point of view of economic science and the socio-economic transformations that have taken place over the past decades. These circumstances determine the purpose of this study - to update scientific knowledge about the state and development trends of the human capital in the Karelian Arctic in the context of the tasks of implementing the special economic regime of the region.

In the development of research tools, the works of leading world [5-7] and Russian [8,9] scientists in the field of human capital research as well as the author's theoretical and methodological research [10] were implemented. The considerable experience of Russian researchers in the study of socio-economic processes in the Arctic was also taken into account [e.g., 11,12].

\section{Materials and methods}

The current research was carried out by a research team in the territory of the Arctic municipalities of the Republic of Karelia: Kemsky, Belomorsky, Loukhsky, Kalevala and Segezha municipal districts and Kostomuksha urban district. The informational basis of the research is the data obtained using the method of mass questionnaire survey of the population in the territory of Arctic Karelia. The sample is multistage and divided into districts, with a quota selection of observation units at the last stage. The first stage is dividing the subjects into districts according to the level of socio-economic development. The second stage - selection of respondents by age and gender quotas, as well as quotas corresponding to the characteristics of living conditions. Only respondents over 18 years old were interviewed. The sampling margin of error does not exceed $3 \%$.

In addition, the information basis of the research includes regulatory acts of various administrative levels, statistical data of the Federal State Statistics Service and its territorial divisions, materials from the websites of local administrations and non-profit organizations.

Measurement method: surveying at the place of residence of the respondents. Sample size: 1102 people aged 18 and over. Technical processing of information was carried out using the SPSS software. Quantitative indicators for the areas of field research in Arctic Karelia include Belomorsky, Kemsky, Loukhsky municipal districts, as well as Segezhsky, Kalevala municipal districts and Kostomuksha urban district, which were included in the AZRF on July 82020.

The main methods used in data analysis: quantitative, statistical, including the analysis of linear distributions, correlation analysis; qualitative, including systematization, generalization of opinions (assessments). 


\section{Results and discussion}

In the course of the study, 1102 people were interviewed on the territory of the Arctic Karelia (Kemsky district - 188 people, Loukhsky district - 125 people, Belomorsky district - 241 people, Kostomuksha urban district - 208 people, Segezha district - 220 people, Kalevala district - 120 people). Among the respondents, women slightly prevailed: $56.2 \%$ versus $43.8 \%$ of men, the average size of households was 2.4 people, among which $61.6 \%$ of families had no underage children. Most of the respondents were at the age of 30-54 $58.7 \%$ (up to 29 years old $-19.9 \%, 55$ years and older $-21.4 \%$ ), had a secondary special / vocational $(40.7 \%)$ or higher $(35.3 \%)$ education, were employed $(73 \%)$ or retired $(16 \%)$.

As the results of the study show, the professional activity of a significant number of the population of Arctic Karelia (44.4\%) corresponds to their qualification. At the same time, most of the respondents who chose the line of work according to their education are located in the Kemsky district (56.4\%).

Men more often than women choose a job in accordance with their education (Table 1). Thus, more than half of the male population in the republic $(50.6 \%)$ work in their field. Among women, there are about $40 \%$ of them. This tendency is typical for both the republic and its regions.

The exception was Kalevala district, where the number of women working in their field of study exceeds the number of men (29.3\% versus $26.9 \%$, respectively). On the other hand, it is in this region that the highest level of non-working men and women is present in comparison with the average for Arctic Karelia (34.6\% and 43.5\% versus 27.2\% and $14.8 \%$, respectively). A possible explanation for this fact is the assignment of this area to the regions of the Far North, which means early retirement of the citizens.

The results of the correspondence of the work area to the received degree, depending on the age of the respondents, seem logical. Thus, the maximum number of respondents working in their field of study is between the ages of 30 and $54(53.9 \%)$. The number of people employed according to their degree under the age of 29 is slightly less $(43.8 \%)$. With an increase in age ( 55 years and older), both the lowest percentage of those working in their field of study among the other selected groups $(18.5 \%)$ and the largest number of non-working citizens $(69.5 \%)$ were noted. A similar trend is typical for most regions of Karelia. The exceptions were Kostomuksha urban district and Kalevala district, in which respondents under the age of 29 work in their degree field more often than those in the age cohort of 30 to 54 years.

As the level of income increases, the number of respondents working in their degree also increases. This tendency was found in all the considered regions of the republic.

Assessing the living standards of their families, more than half of the population of Karelia (51.8\%) confirm their ability to pay for their current needs, clothes and food, however, making larger purchases causes difficulties, and therefore, they are postponed indefinitely. About $8.4 \%$ of respondents, on average, describe their level of income as high, but women are more modest in this definition. Approximately $6.8 \%$ of women indicate this level of income versus $10.6 \%$ of men. The residents of Belomorsk district demonstrate the highest standard of living (14.1\%), although here, too, women are less positive in their assessments than men.

About $9.7 \%$ of middle-aged respondents (from 30 to 54 years old) express complete satisfaction with their own standard of living. Among those who live from paycheck to paycheck, there is a large number of representatives of the older generation (over 55 years old). The most positive assessments in relation to their standard of living are shown by the middle-aged respondents of Belomorsk district (16.7\%), while about $6 \%$ of the respondents aged 30 to 54 in Kalevala district state that they do not have enough money for food. 
Table 1. The correspondence of the workplace to the received degree, depending on the gender of the respondents, in percentage of the number of the respondents.

\begin{tabular}{|c|c|c|c|c|c|c|}
\hline District & Gender & $\begin{array}{l}\text { Work in } \\
\text { one's } \\
\text { degree } \\
\text { field }\end{array}$ & $\begin{array}{c}\text { Work in a } \\
\text { related } \\
\text { field }\end{array}$ & $\begin{array}{c}\text { Work in a } \\
\text { different } \\
\text { field }\end{array}$ & $\begin{array}{c}\text { Do not } \\
\text { have a } \\
\text { degree yet }\end{array}$ & Unemployed \\
\hline \multirow{2}{*}{$\begin{array}{l}\text { Arctic } \\
\text { Karelia }\end{array}$} & male & 50.6 & 7.9 & 22.3 & 4.4 & 14.8 \\
\hline & female & 39.5 & 7.6 & 22.5 & 3.1 & 27.2 \\
\hline \multirow{2}{*}{$\begin{array}{l}\text { Kemsky } \\
\text { district }\end{array}$} & male & 56.3 & 21.9 & 7.8 & 1.6 & 12.5 \\
\hline & female & 56.5 & 7.3 & 19.4 & 1.6 & 15.3 \\
\hline \multirow{2}{*}{$\begin{array}{l}\text { Loukhsky } \\
\text { district }\end{array}$} & male & 49.2 & 3.1 & 18.5 & 9.2 & 20.0 \\
\hline & female & 45.8 & 1.7 & 22.0 & 1.7 & 28.8 \\
\hline \multirow{2}{*}{$\begin{array}{l}\text { Belomorsky } \\
\text { district }\end{array}$} & male & 56.3 & 6.8 & 17.5 & 4.9 & 14.6 \\
\hline & female & 39.1 & 4.3 & 25.4 & 4.3 & 26.8 \\
\hline \multirow{2}{*}{$\begin{array}{l}\text { Kostomuksha } \\
\text { urban district }\end{array}$} & male & 58.8 & 6.7 & 17.6 & 6.7 & 10.1 \\
\hline & female & 25.3 & 16.1 & 21.8 & 8.0 & 28.7 \\
\hline \multirow{2}{*}{$\begin{array}{l}\begin{array}{l}\text { Segezha } \\
\text { district }\end{array} \\
\end{array}$} & male & 38.8 & 5.8 & 41.7 & 0.0 & 13.6 \\
\hline & female & 37.6 & 10.3 & 26.5 & 0.0 & 25.6 \\
\hline \multirow{2}{*}{$\begin{array}{l}\text { Kalevala } \\
\text { district }\end{array}$} & male & 26.9 & 3.8 & 30.8 & 3.8 & 34.6 \\
\hline & female & 29.3 & 5.4 & 18.5 & 3.3 & 43.5 \\
\hline
\end{tabular}

The answers of the respondents when divided into income groups seem to be quite logical. About $86 \%$ of the wealthier respondents have a sufficient level of income to meet their current needs. An identical situation emerged according to the results of a survey of the population in the six studied districts. More often than others, the population of Belomorsk district indicates that "they live in full prosperity and they do not deny themselves anything."

Approximately every second representative of Arctic Karelia (50.6\%) positively assesses the possibility of planning personal income for the year ahead. Every third (29.3\%) resident of Kostomuksha urban district can plan their income for a period up to three years. Planning of personal incomes by men and women on average in the republic does not differ significantly. Short-term planning up to a year is predominant. The overwhelming majority of the two groups under consideration (52.2\% of men and $49.4 \%$ of women) prefer to plan their income for that period. As the planning period increases, the number of respondents who prefer to make personal income plans decreases. About $1.2 \%$ of citizens consider plans for more than five years. Interestingly, in Segezha district, about half of the women $(47.5 \%)$ and $40 \%$ of the men do not plan their personal income at all.

Young people under the age of 29 plan personal incomes most often. Over a third of the respondents over 55 years old do not plan personal income at all. In Loukhsky, Segezha and Kalevala districts, the tendency is somewhat different: it is mostly the middle-aged citizens (30-54 years old) who prefer to plan their personal income for up to a year.

About half of the respondents (45.3\%) with a low income level prefer not to plan their personal income at all. High-income citizens are more active in long-term planning: about $20 \%$ make plans for up to three years. In Loukhsky, Belomorsky districs and Kostomuksha urban district of the republic, a significant number (above the national average) of the respondents with a low income level were recorded, who prefer short-term planning up to a year.

Only a small number of the respondents can plan their family's income for a period of more than five years. Short-term income plans for one year are most in demand by the women $(62.7 \%)$ and the men $(57.6 \%)$ of Loukhsky district.

In different age groups, family income planning does not differ significantly from personal income planning. As the obtained data show, as the age of the respondents 
increases, the desire/ability to plan family income for a five-year period is an insignificant percentage. Interestingly, about $84.4 \%$ of the men in Segezha district generally respond negatively to the question about the possibilities of planning their family's income.

Short-term planning of income (up to 1 year) is typical for both high-income categories of the population and people with a low level of material well-being. A planning period of more than a year is most in demand in a high-income stratum of the population. A significant number of citizens with a low level of income in all the districts of the republic under consideration are characterized by a lack of opportunities for planning their family income.

\section{Conclusion}

In summary, the results of the survey conducted allow us to draw the following conclusions:

1. The population of Arctic Karelia for the most part works in the field of the previously received education. A more pragmatic choice of work in accordance with the received degree is typical for the male population, as well as for persons aged 30 to 54 and with a higher level of income.

2. The majority of the population of the republic considers their living standards as sufficient only to pay for current needs. Inhabitants of Belomorsk district assess their living standards more positively. Women are generally more modest in their assessments of their standard of living than men. Middle-aged people are more optimistic about their standard of living, describing it as "we live in full prosperity, we do not deny ourselves anything".

3. Planning of personal incomes, as well as incomes of their families, by the population of the republic is mostly for a short term. The overwhelming majority of the respondents note the possibility to make plans for their income for a period of no more than a year. Every third resident does not plan their personal income, and a small number of citizens $(1.2 \%)$ have the opportunity to plan income for a longer period (more than five years). Men are characterized by a longer planning period for their personal incomes compared to women. Representatives of the middle age category, as well as those with a high level of income, have the opportunity to plan their income for a longer period.

Further research involves the analysis of factual data collected during fieldwork on the following topical issues of human capital development in the Karelian Arctic:

1. Analysis of the sources of income and material well-being of the population in the context of age and gender groups

2. Existing practices of increasing the human capital among the population by gender and age groups.

The study was conducted within the framework of the state assignment of the Ministry of Science and Higher Education of the Russian Federation "Institutions and social inequality in the context of global challenges and regional restrictions (0218-2019-0090)".

\section{References}

1. Decree of the President of the Russian Federation "On the Strategy for the Development of the Arctic Zone of the Russian Federation and Ensuring National Security for the Period until 2035" No. 645 of October 26, 2020. Available from: http://www.kremlin.ru/acts/news/64274 [Accessed 29th October 2020] 
2. V. Tsukerman, E. Goryachevskaya, S. Ivanov, IOP Conference Series: Earth and Environmental Science 302, 012109 (2019) https://doi.org/10.1088/17551315/302/1/012110

3. Decree of the President of the Russian Federation of June 27, 2017 No. 287 "On amendments to the Decree of the President of the Russian Federation of May 2, 2014 No. 296 "On the land territories of the Arctic zone of the Russian Federation" Available from: http://www.kremlin.ru/acts/bank/42021 [Accessed 29th October 2020]

4. Federal Law of July 13, 2020 N 193-FL "On state support for entrepreneurial activity in the Arctic zone of the Russian Federation" Available from: http://publication.pravo.gov.ru/Document/View/0001202007130047 [Accessed 29th October 2020]

5. M. Blaug, Methodology of Economic Science, or How Economists Explain (Moscow: NP "Journal of Economic Issues", 2004)

6. B. Égert, J. Botev, D. Turner, Eur. Econ. Rev. 129, 103560 (2020) https://doi.org/10.1016/j.euroecorev.2020.103560.

7. O. Attanasio, Journal of the European Economic Association 13, 6, 1, 949-997 (2015) https://doi.org/10.1111/jeea.12159

8. A. Koritskiy, Human capital as a factor of economic growth in Russian regions: a monograph (Nov. Sib. Univ. of Cons. Coop., 2010)

9. V. Samarina, T. Skufina, A. Samarin, European Research Studies Journal 21, 3, 705716 (2018) https://doi.org/10.35808/ersj/1094

10. A. Volkov, G. Kozyreva, A. Morozov, Economic systems management 11 (2017)

11. V. Tatarkin, V. Litovskiy, MSTU Bulletin 3, 573-587 (2014)

12. S. Baranov, T. Skuf'ina, I. Gushchina, Economic and social changes: facts, trends, forecast 1, 160-173 (2020) 